Journal of Humanities and Social Sciences Studies (JHSSS)

ISSN: 2663-7197

DOI: 10.32996/jhsss

Journal homepage: www.al-kindipublisher.com/index.php/jhsss

\title{
The Kurds of Northern Syria: Governance, Diversity, and Conflicts: Book Review
}

ISLAM SARGI

ISLAM SARGI, PhD Candidate, Department of Contemporary Comparative History, University of Szeged

Corresponding Author: ISLAM SARGI, E-mail: iszeged509@gmail.com

\section{ARTICLE INFORMATION ABSTRACT}

Received: October 02, 2020

Accepted: November 25, 2020

Volume: 2

Issue: 6

DOI: 10.32996/jhsss.2020.2.6.28

KEYWORDS

Identity, Review, The Kurds, Syria, Representation
The purpose of this paper is to present a review of The Kurds of Northern Syria: Governance, Diversity, and Conflicts written by Harriet Allsopp and Wladimir van Wilgenburg, granted by the International Development Research Center, (IDRC), Ottawa, Canada Iraq Studies (IIST), First Published in Great Britain, 2019.

Since the Middle East has experienced for a long time a constantly changing political and social structure, the studies on its politics and societies require constant updating to interpret the field's realities. Harriet Allsopp ${ }^{2}$ and Wladimir van Wilgenburg ${ }^{3}$ in their study titled The Kurds of Northern Syria: Governance, Diversity, and Conflicts explore this "reality". The book, which primarily focuses on the Kurdish identity, representation, and the multilingual structure of the region in Syria, contributes new dimensions to the literature due to its field research based on interviews with local politicians, civilians, and members of non-governmental organizations. The book, which consists an introduction and six sub-chapters, sheds light on the diversity of sources, as well as the theoretical and historical framework, not only about Syrian Kurds but also the debates on identity and representation in the Middle East.

Referring to Abdullah Ocalan, the authors discuss identity and representation in reference to Kurds; they state that for the Kurdish movement, the nation is based on democratic citizenship, not ethnicity and language. In the new period known as democratic confederalism, this definition has transformed into a representation model based on diversity. They claim that the Kurdish identity is fragmented due to the Kurds' division within the borders of the four nation states and the pressures on their language and identity and that being a Kurd reveals a different understanding in different situations and geographies.

The Kurdish identity-which was previously shaped by the laws of the Syrian state, political parties, and organizations-was freed from these pressures after the Syrian civil war started in 2011 and the ISIS was repulsed by the armed Kurdish groups. Additionally, according to a survey conducted by the authors, $47 \%$ of the participants expressed that they experienced a change in their identity perception during the war. Although the state pressure on the Syrian Kurds has ended and the PYD's self-government project has enabled the expression and representation of the Kurdish identity, the authors draw attention to important questions such as the democracy of this new form of representation and how it can spread to the whole of Syria. The authors claim that representation has been resolved in this new project, but the local, state, and pan-state identities still remain active.

The analysis of the Kurdish parties established in 1957 in Syria, the KNC, and finally the PYD and their comparison in many respects, such as political values and their aimed future of Syria, are among the book's critical debates. By making a detailed

K C AL-KINDI CENTER R D FOR RESEARCH AN Your gatewoy to world-class resecrch
Published by Al-Kindi Center for Research and Development. Copyright (c) the author(s). This is an open access article under CC BY license (https://creativecommons.org/licenses/by/4.0/)

\footnotetext{
${ }^{2}$ Harriet Allsopp is a researcher who specializes in the Middle East, with a focus on Syrian Kurds and Kurdish politics, and is the author of The Kurds of Syria: Political Parties and Identity in the Middle East.

${ }^{3}$ Wladimir van Wilgenburg is a journalist and writer whose work predominantly focusses on the Kurds and Kurdistan. 
presentation of the intercultural division in terms of historical continuity and changes, they claim that these blocks are strictly different from each other. One of the book's central arguments is the claim that the historical and political order of Syria and the differences between these blocs are influential in the shaping and representation of the Kurdish identity.

Presenting a genealogy of the Kurdish parties since 1957, the authors present a historical analysis while also showing the Kurdish political spectrum and internal differences and divisions among the Kurdish political blocs in Syria. The book emphasizes that the political pragmatism of the PYD, which rose significantly with the start of the Syrian civil war, is vital in demonstrating social mobilization. While the parties in 1957 were based on a reticent adherence to the Kurdish traditions, it is argued that they considered modernization to a greater degree to preserve this identity. One of these parties' most important characteristics is the distant approach to the word "Kurdistan" and their agenda focused on reform rather than revolution in Syria.

Founded in 2011, KNC has brought together many political parties and activists. The primary purpose of this "multi-party" structure is to gather the representation of the Kurds under one roof and to communicate with other groups in Syria. However, the strategy between the parties and the vision of both Syria and the Kurds has created a division, which leads some to become closer to the PYD. The parties in 1957 never resorted to an armed struggle against the Syrian state. Even with the outbreak of the civil war, while there were always discussions of peaceful struggle, the KNC refused to join the Syrian Democratic Forces. While parties and entities whose roots date back to 1957 found it difficult to adapt to the civil war's changing relativity, the PYD, by creating an armed struggle, followed a more pragmatic approach and chose to take advantage of the vacuum created by the war.

The study, which gives a significant place to the administration, known as "self-rule" or "democratic confederalism" in the literature, focuses on both the changing and transforming structure and practices of the new administration style since 2014. The authors state that such transformation aims to de-ethicize the administration, gain acceptance from different social segments, and provide external support. The authors, who examine this new form of government established by the Kurds from many aspects, such as security, education, media, and bureaucracy, demonstrate that such a system based on representation rather than ethnic identities could establish autonomy under war conditions. However, they also emphasize that non-Kurdish Syrian groups' existence is an essential obstacle to such a system.

Emphasizing that the Syrian civil war is also an expression of the necessity of an essential political and social transformation, the authors claim that the system established under the priority of the PYD and other organized Kurdish structures provides significant breaks in the perception of identity and the representation of identities. However, based on the surveys conducted, the authors found that some Kurds continue to have a traditional perception of identity and nationalism. At the same time, some express their identity with religious references, especially from ISIS, and some put military structures such as the YPG above everything else. In this framework, the authors argue that the Kurds benefit from the new representation and rights since the beginning of the Syrian war; they also explore whether such an administrative system will continue the social revolution in the future.

The Syrian civil war, which has turned into a war of interest not only a the national but also at the regional and global levels, has benefited and sometimes created obstacles due to the actors' attitudes toward each other and the relations of different groups with these actors. The authors state that there are still meaningful obstacles and questions facing the revolution that emerged during the multi-layered, multi-actor Syrian civil war. Based on the representation of identities, they draw attention to the uncertainty of whether the vast majority will adopt this new form of democracy. Similarly, the possibility that the rest and its autonomous administration will not accept YPG's ideological attitude which will be directly affected by the regional and global actors' attitudes. It is pointed out that it will play a significant role in the revolution's future in question. Emphasizing that there is a Kurdish policy that has undergone an irreversible transformation with the Syrian civil war, the authors emphasize that although regional and global actors are included, the Syrian Kurds' representation remains a vital conflict area.

Who are the Kurds? What is Kurdishness? Is there a single Kurdish identity and a single expression of this identity? Do all Kurds perceive Kurdishness in the same way? What role do regional and global actors play in the future of the Rojava revolution / democratic confederalism? What historical and political processes did the democratic self-government, a new form of democracy, undergo in Kurdish politics, identity, when this identity is put into practice? The book, which claims to answer these and many similar fundamental questions, provides crucial and enlightening answers for academics, students, and researchers who seek to understand contemporary Middle Eastern politics; and Kurdish politics; and the multi-actor 
structure of the Syrian civil war. This comprehensive study reveals that the Syrian civil war and the different tendencies between the Kurdish people are a breaking point for the political and bureaucratic changes and conversion of the Kurdish identity and, makes notable contributions to the literature of the Kurdish identity and democratic confederalism.

\section{References}

Allsopp H., \& van, W. (2019). The Kurds of Northern Syria: Governance, diversity and conflicts, I.B. TAURIS. 